\title{
THE SLAV RECEPTION OF GREGORY OF NYSSA'S WORKS: AN OVERVIEW OF EARLY SLAVONIC TRANSLATIONS
}

\section{LARA SELS}

Although a lot has been written about the "translatio" of Byzantine Christianity in the mediaeval Slavia orthodoxa, advancing a critical assessment of the Slav reception of the Greek Fathers remains a precarious undertaking. Although the mere listing of patristic texts in Slavonic translation obviously falls short of the demands of the subject, a notion of the corpus of translated texts is called for. ${ }^{1}$ The modest aim of the present article, which deals with the reception of Gregory of Nyssa among the orthodox Slavs, is first and foremost to establish the nature and the range of the material reception of his writings by means of an overview of Old Slavonic translations of his works and of substantiated traces of influence of his writings on Slavonic texts, from the time of the Moravian mission (863) throughout the Slav Middle Ages and up to the 16th century. ${ }^{2}$

After the Moravian Mission and the ensuing Cyrillomethodian period during which liturgical texts and parts of the Bible were made available for the Christianization of the Slavs, ${ }^{3}$ the next locus of

\footnotetext{
${ }^{1}$ Research into Slavonic translation literature is often hampered by practical obstacles such as the poor cataloguing of Slavonic manuscripts, erroneous ascriptions of texts both in manuscripts and manuscript catalogues, a lack of comprehensive inventories and incipitaria etc.; cf. Christian Hannick: Maximos Holobolos in der kirchenslavischen homiletischen Literatur. Wiener byzantinistische Studien 14 (Vienna: Verlag der Österreichischen Akademie der Wissenschaften, 1981), 25: "An eine 'Clavis patrum slavicorum' oder an eine 'Bibliotheca hagiographica slavica' zu denken-so erwünscht auch immer derartige Unternehmen wären-, gehört für unsere Generation dem Bereich der Träume an." However, Francis Thomson has pursued the compilation of a bibliography "of all translations into Slavonic from the dawn of Slav letters down to the death of Peter the Great in 1725" since the Nineteen-sixties; see the introductory remarks in Francis Thomson: The Reception of Byzantine Culture in Mediaeval Russia. Collected studies series 590 (Aldershot: Ashgate, 1999), ix-xxii.

2 This contribution owes much to previous scholarship, particularly to the work of Francis Thomson, who was so kind as to allow the author to use his personal library and card catalogue.

${ }^{3}$ For Cyrillus and Methodius and the origins of Slavonic translation literature, see e.g. Gerhard Podskalsky: Christentum und theologische Literatur in der kiever Rus': (988-1237) (München: Beck, 1982), 56-61.
} 
flourishing translation activity was 10th-century Bulgaria, ruled by the cultivated "half-Greek" Symeon (893-927) and his son Peter (927969). Numerous homilies of Greek Church Fathers, including Gregory of Nyssa, ${ }^{4}$ were translated as well as Vitae and Passiones of saints, the selection of which was based on the rules of the liturgical and monastic typikon. ${ }^{5}$ In this "Golden Age" of Old Slavonic book culture, literary activity was primarily driven by the need of the nascent Bulgarian Church to proclaim and consolidate the basic principles of Christianity. This is exemplified, for instance, by the way in which John the Exarch (9th-10th century) accommodated parts of Gregory of Nyssa's writings to his intentions by including them in his main works, ${ }^{6}$ viz. a partial translation of John Damascene's Expositio fidei called Bogoslovie or "Theology" and a work on the six days of creation, the Šestodnev or "Hexaemeron", ${ }^{8}$ both meant to buttress the new faith and to defend it against heresy. ${ }^{9}$ Not only classical Greek philosophy but also learned dogmatic theology was lost on the Slav neophytes and accordingly none of Gregory of Nyssa's important dogmatic writings-nor indeed any of his ascetical or exegetical works-was translated in full in this period. Translations of legal texts, on the contrary, were needed to regulate both the civil and the ecclesiastical apparatus, and Gregory's

\footnotetext{
${ }^{4}$ See infra part 4.

${ }^{5}$ See e.g. Francis Thomson: "Continuity in the Development of Bulgarian Culture during the Period of Byzantine Hegemony and the Slavonic Translations of Works by the three Cappadocian Fathers," in: Meždunaroden simpozium 1100 godini ot blaženata končina na sv. Metodij, vol. 2, ed. by Nikolaj Kocev (Sofija: Sinodalno izdatelstvo, 1989), (140-153) 143.

${ }^{6}$ For John the Exarch see e.g. Gerhard Podskalsky: Theologische Literatur des Mittelalters in Bulgarien und Serbien 865-1459 (München: Beck, 2000), 228-233.

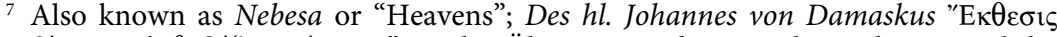

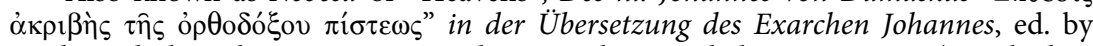
Linda Sadnik, vol. 1. Monumenta linguae Slavicae dialecti veteris 5 (Wiesbaden: Otto Harrassowitz, 1967); vol. 2. Monumenta linguae Slavicae dialecti veteris 14; vol. 3. Monumenta linguae Slavicae dialecti veteris 16; vol. 4. Monumenta linguae Slavicae dialecti veteris 17 (Freiburg im Breisgau: Weiher, 1981-1984); for the translation, which contains only 48 of the 100 chapters of the Expositio fidei, see Podskalsky: Theologische Literatur des Mittelalters in Bulgarien und Serbien 865-1459 (see note 6), 241-243.

${ }^{8}$ Das Hexaëmeron des Exarchen Johannes, ed. by Rudolf Aitzetmüller, 7 vols. (Graz: Akademische Druck- und Verlagsanstalt, 1958-1975); for a description of this compilatory work, the main sources of which are Basil of Caesarea's Homiliae IX in Hexaemeron and Severian of Gabala's In cosmogoniam orationes VI, see Podskalsky: Theologische Literatur des Mittelalters in Bulgarien und Serbien 865-1459 (see note 6), 228-232.

9 See infra parts 1 and 2.3 .
} 
canonical letter addressed to Letoius of Melitene was translated as a part of the Syntagmata xiv titulorum. ${ }^{10}$

It has been claimed that after the fall of Preslav and the subsequent Byzantine annexation of the first Bulgarian empire (1018) the torch was handed over to recently converted Kievan Russia and a multitude of translations from Greek were made during the reign of Jaroslav the Wise ( $† 1054)$ and afterwards up to the 13th century when Kiev fell to the Mongols (1240). While it is true that East Slav literary culture was heir to the Bulgarian recension of Byzantine ecclesiastical literature, the claim that numerous new translations were produced has been subject to criticism. ${ }^{11}$ Within the context of this discussion divergent conclusions have been drawn, for instance, as regards the time of origin and the Bulgarian or East Slav provenance of a catena on the Song of Songs, including a substantial part of Gregory of Nyssa's In canticum canticorum. ${ }^{12}$

The production of Slavonic translations in Bulgaria stagnated during the period of Byzantine rule, but the revolt of the Asen brothers of 1185 led to the establishment of the second Bulgarian empire, where, by the time of John Alexander's reign (1331-1371), book culture flourished once more. An important contribution to this "Silver Age" of old Slavonic literature was also made in Serbia, especially during the reigns of Stephen Dušan (1331-1355) and his successors. The cultural efflorescence of the turbulent 14th century bore the mark of the monastic revival of hesychasm and it has been claimed that the popularity of this spiritual movement stirred people's interest in the mystical works of Fathers who, like Gregory of Nyssa, had influenced the hesychast protagonists. ${ }^{13}$ A full Serbo-Slavonic translation of Gregory's treatise De hominis opificio was indeed completed around the middle of the 14th century. ${ }^{14}$ The language of this translation bears witness to the orthographic, linguistic and stylistic novelties inspired by the Greek models and typical of the 14th century. This shift of paradigms has been linked to the so-called "Tărnovo school" associated with the last

\footnotetext{
10 See infra part 5.

${ }^{11}$ Cf. e.g. Thomson: The Reception of Byzantine Culture in Mediaeval Russia (see note 1 ), xiii.

${ }^{12}$ See infra part 2.1.

${ }^{13}$ See Thomson: "Continuity in the Development of Bulgarian Culture during the Period of Byzantine Hegemony" (see note 5), 144.

${ }^{14}$ See infra part 2.3 .
} 
Bulgarian patriarch, Euthymius of Tărnovo (patriarch c. 1375-1393). ${ }^{15}$ The latter's acquaintance with Gregory of Nyssa is known from one of his letters, which contains a large fragment from De anima et resurrectione. ${ }^{16}$ However, the end of the 14th century saw the conquest of the great South Slav empires by the Ottoman Turks, which marked not so much the immediate cessation as the beginning decline of the Bulgarian literary tradition. Despite the increase in literary activity in the 14th century, the selection of Byzantine ecclesiastical literature remained narrow in that it still answered first and foremost the requirements of the liturgy and the monastic life. Hagiography became a key genre and the change of literary norms caused the want of new translations of homiletic and hagiographic texts to be strongly felt. Some of Gregory of Nyssa's sermons were translated for the first time, while new ones were made to replace existing ones. ${ }^{17}$ The fact that Gregory's Vita Macrinae was translated in this period was due not so much to the merits of the Vita as an ascetic treatise but rather to the fact that it was a Vita. ${ }^{18}$

In the 15th century Russia had shook off the "Mongol yoke" and Moscow's rise to power resulted in the incorporation of the Russian principalities and the development of a centralized Moscovite state. The fall of Constantinople in 1453 was blamed on the Greek Church for its concessions to the West and Muscovy came to see itself as the sole defender of Orthodoxy. The compilation of a large Menologium of encyclopaedic proportions completed under the direction of Macarius, Metropolitan of Moscow and All Russia (1542-1563) ${ }^{19}$ was one of the means to glorify Moscow as the "Third Rome." However, as the Western impact on Muscovy grew the Byzantine influence declined and while a few new translations of patristic works were made during the 15th century, in the 16th century they were more often made from Latin than from Greek. There were notable exceptions. The Athonite monk Maximus (lay name Michael) Triboles (c. 1475-1556)-better known as Maximus the Greek-arrived in Moscow in 1518 to work as a

\footnotetext{
${ }^{15}$ For Euthymius see e.g. Podskalsky: Theologische Literatur des Mittelalters in Bulgarien und Serbien 865-1459 (see note 6), especially $252 \mathrm{f}$.

${ }^{16}$ See infra part 1.

17 See infra part 4

${ }_{18}$ See infra part 3.

19 For Macarius' Menologium, see e.g. Dmitrij Čiževskij: History of Russian Literature: From the eleventh century to the end of the Baroque ('s-Gravenhage: Mouton \& Co., 1962), 300-303.
} 
translator following a request from Basil III of Muscovy (1479-1533). ${ }^{20}$ Maximus was to spend the rest of his life in Russia. His numerous translations include Gregory of Nyssa's In orationem dominicam. ${ }^{21}$ The "Time of Troubles" and the interregnum preceding the establishment of the Romanov dynasty marks the end of this survey, which does not discuss the explosion of translations produced in the 17 th century, when Muscovy had to appeal to translators from Western-influenced Belorussia and Ukraine for want of domestic scholars with a sufficient knowledge of Greek.

To say that the Orthodox Slavs were heir to all aspects of Byzantine theology and literature is a distortion of the truth. Whereas homiletics, hagiography and popular exegesis flourished on Slav soil, philosophy and dogmatic theology failed to take root. It is hardly surprising that the impact of the writings of Gregory of Nyssa-the "philosopher" of the Cappadocian Fathers-was slim.

\section{Dogmatic Treatises-De anima et resurrectione (fragments)}

Although minor fragments from Gregory's Oratio catechetica (CPG 3150) and Contra Eunomium (CPG 3135) ${ }^{22}$ and excerpts from his dialogue De anima et resurrectione (CPG 3149) can be found integrated in other texts and text collections, the larger part of their contents and the quintessence of their teaching remained unknown to the Slavs. Moreover, Gregory's minor writings on Trinitarian issues, dealing with the refutation of Arianism and Appolinarianism, did not leave their imprint on mediaeval Slav Orthodoxy. An abridged and freely translated passage of Gregory's dialogue De anima et resurrectione ${ }^{23}$ was added to John the Exarch's Bogoslovie as one of six appendices. ${ }^{24}$

\footnotetext{
${ }^{20}$ For Maximus see e.g. Čiževskij: History of Russian Literature (see note 19), 291300 and Hugh Olmsted: "A Learned Greek Monk in Muscovite Exile: Maksim Grek and the Old Testament Prophets," Modern Greek Studies Yearbook 3 (1987), 1-73.

${ }^{21}$ See infra part 2.4.

${ }^{22}$ See infra part 6.

${ }^{23}$ An. et res. 137-152 (BKV I 1, 142,31-160,31 Oehler).

${ }^{24}$ See Roland Marti: Handschrift-Text-Textgruppe-Literatur: Untersuchungen zur inneren Gliederung der frühen Literatur aus dem ostslavischen Sprachbereich in den Handschriften des 11. bis 14. Jahrhunderts. Veröffentlichungen der Abteilung für Slavische Sprachen und Literaturen des Osteuropa-Instituts (Slavisches Seminar) an der Freien Universität Berlin 68 (Berlin: Otto Harrassowitz, 1989), 207; Thomson: "Continuity in the Development of Bulgarian Culture during the Period of Byzantine Hegemony" (see note 5), 143 and Podskalsky: Theologische Literatur des Mittelalters in
} 
Moreover, some elements from Gregory's text, esp. the section on the coexistence of body and soul, ${ }^{25}$ were subtly integrated in the sixth book of John's Šestodnev. ${ }^{26}$

Another fragment from De anima et resurrectione was translated in the second half of the 14th century, when it was included in a letter from patriarch Euthymius of Tărnovo to hegoumenos Nicodemus of Tismana ( $\dagger 1406) .{ }^{27}$ The letter, erotapocritical in structure, contains six question-and-answers on angelology, demonology and anthropology. The excerpt from Gregory's De anima et resurrectione $e^{28}$ on the godlikeness of the soul and on the passions, is to be found at the end of the sixth answer. Euthymius' answer itself touches on the three com-

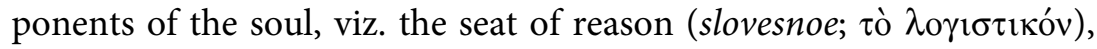

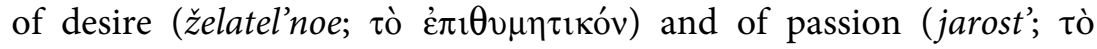
$\left.\theta 0 \mu o \varepsilon 1 \delta \varepsilon \varepsilon_{\varsigma}\right){ }^{29}$ and calls to mind another fragment from De anima et resurrectione. ${ }^{30}$

\section{Exegetical works}

When dealing with Gregory of Nyssa's exegetical works, one cannot fail to notice the absence of full translations of key works such

Bulgarien und Serbien 865-1459 (see note 6), 243. The excerpt has been published by Linda Sadnik: "Die Bruchstücke aus Väterschriften im Anschluß an die Übersetzung

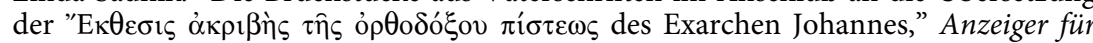
slavische Philologie 12 (1981), (133-189) 152-169; three more appendices were taken from Gregory's De hominis opificio [see infra part 2.3].

${ }^{25}$ An. et res. 108-128 (BKV I 1, 108,11-134,2 Oehler).

26 See Lara Sels: "John the Exarch and his Sources: New Sources of the Sixth Book of the Šestodnev," Slavica Gandensia 35 (2008), (123-149) 127-139, notes 26.31.34.41.

${ }^{27}$ Werke des Patriarchen von Bulgarien Euthymius (1375-1393), ed. by Emil Kałuzniacki (Vienna: Carl Gerold, 1901 [reprinted London: Variorum Reprints, 1971]), (205-220) 216-220. For Nicodemus e.g. Podskalsky: Theologische Literatur des Mittelalters in Bulgarien und Serbien 865-1459 (see note 6), 254 note 1108.

${ }_{28}^{28}$ An. et res. 89-97 (BKV I 1, 90,7-98,10 Oehler).

29 This tripartite division, which is found both in Plato's Republica and in the image of the charioteer in Phaedrus, recurs in Gregory's "Canonical Letter" [see infra part 5].

${ }_{30}$ An. et res. 48-68 (BKV I 1, 40,30-64,5 Oehler). Remote echo's of the same fragment on anger and desire recur in a letter of Metropolitan Nicephorus I of Kiev (1104-1121) to prince Vladimir Monomach (1053-1125); the most recent edition is Vladimir Mil'kov: Mitropolit Nikifor (Saint-Petersburg: Mir, 2007), 248-262; the letter, addressing questions concerning the personal ascesis of the souvereign and control over the senses, was probably written in Greek by the prelate before being translated to Old Russian, see Podskalsky: Christentum und theologische Literatur in der kiever Rus' (see note 3), 146-149.177.287. 
as the De vita Moysis (CPG 3159), the homilies In canticum canticorum (CPG 3158) or the homilies De beatitudinibus (CPG 3161). Only fragments of these works survive, viz. as excerpts in catenae or in anthologies, ${ }^{31}$ while passages from the Apologia in Hexaemeron (CPG 3153 ) are found as interpolations in a translation of Basil of Caesarea's Homiliae in Hexaemeron (CPG 2835). In fact, the latter translation is closely connected to one remarkable exception in the exegetical field, viz. a translation in full of Gregory's De hominis opificio, appended to Basil's homilies in all known manuscripts. Other exegetical works such as the two essays on the titles of the Psalms, In inscriptiones psalmorum (CPG 3155), ${ }^{32}$ or the eight homilies In Ecclesiasten (CPG 3157) seem to have remained unknown to the Slavs, while a translation of the larger part of the five homilies De oratione dominica (CPG 3160) was not made until the 16th century.

\subsection{In canticum canticorum (fragments)}

Numerous short excerpts from throughout Gregory's commentary In canticum canticorum are found in a Slavonic translation of an untraced Greek Catena in canticum canticorum, ${ }^{33}$ added to an early translation of In canticum canticorum. Although it has been claimed that the translation of the catena-which has been preserved in East Slav text witnesses only-was made in Kievan Russia or at least by East

\footnotetext{
${ }^{31}$ See infra part 6.

${ }^{32}$ It is known that a large catena on the Psalms, translated in 1518-1519 by Maximus the Greek, contained a few short passages from Gregory of Nyssa's writings, as is stated by the translator himself in a letter to Grand Prince Basil III of Muscovy: "In the same manner [are] also [included] of Gregory the Theologian very short fragments as well as of his namesake and true friend, I mean [Gregory] of Nyssa, since they appear four or five times in the whole book"-translated from the edition of the letter by A. Langeler: Maksim Grek: Byzantijn en humanist in Rusland, ed. by Arno Langeler (Amsterdam: Uitgeverij Jan Mets, 1986), 224.

${ }^{33}$ See Francis Thomson: "Made in Russia: A Survey of the Translations Allegedly Made in Kievan Russia," in: Millennium Russiae Christianae: Tausend Jahre Christliches Russland 988-1988: Vorträge des Symposiums anlässlich der Tausendjahrfeier der Christianisierung Russlands (Münster 5.-9. Juni 1988), ed. by Gerhard Birkfellner (Köln: Böhlau, 1993), (295-354) 312, also Marti: Handschrift-Text-TextgruppeLiteratur (see note 24), 140.146, and Anatolij Alekseev: Pesn' pesnej v drevnej slavjano-russkoj pis'mennosti (Saint-Petersburg: Dmitrij Bulanin, 2002), 40-62. The other sources of the catena are Philo of Carpasia's Enarratio in Canticum Canticorum, Hippolytus of Rome's Commentarius in Canticum canticorum and Procopius of Gaza's In cantica canticorum selectarum expositionum epitome. An edition of the Slavonic translation can be found in Alekseev: Pesn' pesnej v drevnej slavjano-russkoj pis'mennosti (see note 33), 63-122, who also identified the c. 80 short parallels with the Greek text.
} 
Slav translators, ${ }^{34}$ linguistic evidence points to 10 th century Bulgaria as the time and place of origin. ${ }^{35}$

Some parts from Gregory's Comments on In canticum canticorum occur in a 15th century Slavonic version of another catena, viz. an abridgment of the Catena trium patrum $\left(\mathrm{CPG} \mathrm{C} 81 \mathrm{~B}^{2}\right)$, the major part of which consists of Theodoret of Cyrrhus' Explanatio in canticum canticorum (CPG 6203). The translation is mostly ascribed to Constantine of Kostenec ( $\dagger$ after 1431). ${ }^{36}$

\subsection{Apologia in Hexaemeron (fragments)}

A 14th century Slavonic translation of Basil of Caesarea's Homiliae in Hexaemeron contains six interpolations from Gregory of Nyssa's Apologia in Hexaemeron. ${ }^{37}$ The excerpts go back to scholia in the Greek exemplar of Basil's Homiliae and they were translated along with the rest of the text. As is clear from previous research and from the Praefatio to the recent edition of the Greek Apologia, parallels for the Slavonic fragments can be found in the margins of some of the Greek manuscripts. The section on the scholia in the Praefatio to the edition, ${ }^{38}$ does not include a parallel for the first Slavonic fragment, ${ }^{39}$ but there can be no doubt that it figured in the Slav translator's Greek

${ }^{34}$ For instance Alekseev: Pesn' pesnej $v$ drevnej slavjano-russkoj pis'mennosti (see note 33), 59-61.

${ }_{35}$ See the arguments of Horace Lunt: "The OCS Song of Songs: One Translation or Two?," Die Welt der Slaven 30 (1985), (279-318) 292-304.

${ }^{36}$ For the reference to Gregory of Nyssa see Borjana Christova: "Tălkuvanija na starozevetni i novozavetni knigi v srednovekovnata bălgarska kultura," Palaeobulgarica 18/2 (1994), (76-81) 78, who also mentioned fragments from Nilus of Ancyra, Michael Psellus and 'Maximus the Rhetorician', viz. Maximus Confessor. This version of the Song with comments has only been preserved in full in one 15th century manuscript, viz. Codex Rila (Bulgaria), Monastery of St John 2/24 (37), f. 115-241.

${ }^{37}$ For earlier research on the Slavonic Homiliae in Hexaemeron, see Lara Sels: Gregory of Nyssa, De hominis opificio: O obrazè člověka: The Fourteenth-Century Slavonic Translation. A Critical Edition with Greek Parallel and Commentary. Bausteine zur slavischen Philologie und Kulturgeschichte, N.F. Reihe B. Editionen 21 (Köln: Böhlau, 2009), 19f. The translation has not yet been published. The earliest manuscript containing the text is Codex Athos, Chilandar Monastery 405, f. 1r-101v (c. 1400); four other text witnesses are known, all of South Slav origin, dated to the 15th and 16th centuries.

${ }^{38}$ Hubertus R. Drobner: "Praefatio," in: Gregorii Nysseni In Hexaemeron, ed. idem. Gregorii Nysseni Opera IV/1 (Leiden: Brill, 2009), xcviii-cv.

$39 \sim$ Hex. (GNO IV/1, 28,12-29,17 Drobner). 
model. The remaining five fragments correspond to scholia III, ${ }^{40} \mathrm{IV},{ }^{41}$ $\mathrm{II},{ }^{42} \mathrm{VII},{ }^{43}$ and VI. ${ }^{44}$

\subsection{De hominis opificio}

The first Slav translator to deal with Gregory's De hominis opificio was John the Exarch, who translated chapters $25-27,{ }^{45}$ as appendices to his Bogoslovie ${ }^{46}$ together with the above-mentioned excerpt from the De anima et resurrectione. ${ }^{47}$ Moreover, the De hominis opificio has recently been identified as a source for the Exarch's Šstodnev. ${ }^{48}$ The subtle influence of Gregory's treatise is clear from passages in the sixth book, where John elaborates on the creation of man. He never actually proceeds to translate but rather paraphrases and refers to the Cappadocian father, with whom he often disagrees. ${ }^{49}$ One of the reasons for John's circumspect treatement is his awareness of the claim that parts of Gregory of Nyssa's works were interpolated by heretics. ${ }^{50}$

40 Drobner: "Praefatio" (see note 38), c-ci.

${ }^{41}$ Drobner: "Praefatio" (see note 38 ), ci-cii.

42 Drobner: "Praefatio" (see note 38), xcix-c.

${ }^{43}$ Drobner: "Praefatio" (see note 38), ciii-cv. The Slavonic text is complete, while the end of the seventh scholion is missing in the printed Greek text page cv: "Das Scholion bricht ab, weil die folgenden Pergamentblätter durch Papierseiten ersetzt wurden, die zwar den Text kopieren, aber keine Scholien und Glossen [...]. Man wird

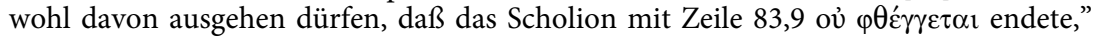
which is correct according to the Slavonic tradition.

${ }^{44}$ Drobner: "Praefatio" (see note 38), cii-ciii. The Slavonic fragments can be found on f.11r-11v, 19v, 21r-21v, 23r-23v, 24vb-25vb and 24ra-24v of the Chilandar manuscript; see Sels: Gregory of Nyssa, De hominis opificio: O obrazě člověka (see note 37), $100 f$.

${ }_{45}$ Op. hom. 26-28 (Gregorii Nysseni quae supersunt omnia [...], edidit George H. Forbes [Burntisland: Pitsligo Press, 1855], 250,19-274,25).

${ }^{46}$ Linda Sadnik: "Die Bruchstücke aus Väterschriften im Anschluß an die Überset-

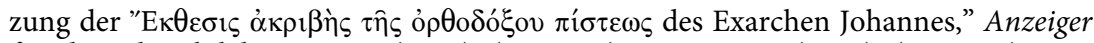
für slavische Philologie 10-11 (1979), (163-187) 165-187; 12 (1981), (133-189) 135151.

47 See supra part 1.

${ }^{48}$ See Sels: "John the Exarch and his Sources" (see note 26), passim.

49 E.g. as regards the sequence of the creation of body and soul-cf. Sels: "John the Exarch and his Sources" (see note 26), 127-139.

${ }^{50}$ The Exarch explicitly states: "Deshalb müssen wir auch verstehen, daß das nicht die eigene Lehre des großen Kirchenlehrers ist, sondern daß sie verderbt ist von den Haeretikern, die ihre eigenen schlechten Lehren hineinmischen, gleichsam wie Gift in den Honig streuen, damit man nach diesen Worten auch seine anderen Lehren nicht (mehr) annähme. So wie der ehrwürdige Gregorius der Abstammung nach der wirkliche Bruder des großen Basilius ist, so auch im Geiste, im Glauben, im guten Willen, ein Wahrhafter und in nichts geringer als jener, sondern erfüllt von jeglicher 
However, the middle of the 14th century saw the completion of a full and extremely literal Serbo-Slavonic translation of the De hominis opificio, ${ }^{51}$ appended to a translation of Basil's nine Homiliae in Hexaemeron $^{52}$ as the second part of a bipartite "Hexaemeron corpus". ${ }^{53}$ The influence of the Slavonic Hexaemeron collection never exceeded its initial orbit, viz. Athos and a region covering present-day Montenegro, Kosovo and the south of Serbia, North Macedonia and West Bulgaria. In view of the limited distribution of the text witnesses and the obscurity of the translation it is absolutely unwarranted to speak of a real assimilation of the theological views expressed in the De hominis opificio.

\subsection{In orationem dominicam orationes $\mathrm{V}$}

Excerpts from Gregory's homilies in orationem dominicam can be found in the Florilegium of Symeon, which was translated from a large Byzantine collection, the so-called $\Sigma \omega \tau \eta$ pros, during the reign of Symeon of Bulgaria (893-927). ${ }^{54}$ The core of the collection consists of 88 Quaestiones et responsiones ascribed to Anastasius Sinaita, each of which is followed by a string of quotations from the Fathers and other authors. Amongst these are, in parts much revised, fragments from the second and fourth homilies De oratione dominica. ${ }^{55}$

Kunst und Weisheit. An vielen Stellen sind nämlich in seine Lehre solche nicht richtigen Theorien hinein gemischt worden, von den Leuten, die es sich zur Gewohnheit machen, den wahren Glauben vielerorts zu zerstören."-German translation by Aitzetmüller (ed.): Hexaëmeron (see note 8), vol. 6, 103-105.

${ }^{51}$ Cf. Sels: Gregory of Nyssa, De hominis opificio: O obrazě člověka (see note 37), \#\#page/s\#\#.

${ }_{52}$ See supra part 2.2.

${ }^{53}$ For the Greek "Hexaemeron corpus" and its variants, see Emmanuel Amand de Mendieta and Stig Y. Rudberg: Basile de Césarée: La tradition manuscrite directe des neuf homélies sur l'Hexaéméron: Étude philologique. Texte und Untersuchungen zur Geschichte der altchristlichen Literatur 123 (Berlin: Akademie Verlag, 1980), 2-4; also Sels: Gregory of Nyssa, De hominis opificio: O obrazě člověka (see note 37), 8f. for the Greek tradition, 20f. for the Slavonic version.

${ }^{54}$ Simeonov sbornik (po Svetoslavovija prepis ot $1073 \mathrm{~g}$.). Vol. 1: Izsledvanija i teksti, ed. by Petăr Dinekov (Sofija: Bălgarska akademija na naukite, 1991); for the collection, see e.g. Douwe Sieswerda: “The $\Sigma \omega \tau$ pros, the Original of the Izbornik of 1073," Sacris erudiri 40 (2001), 293-327, and Francis Thomson: "A comparison of the contents of the two translations of the Symeonic Florilegium with the Greek original," KiriloMetodievski studii 17 (2007), 721-758.

55 Or. dom. (GNO VII/2, 23,23-25,5; 29,14-27; 55,21-56,9 Callahan). The fragments supplement the answers to questions one and eleven; Dinekov (ed.): Simeonov sbornik (po Svetoslavovija prepis ot 1073 g.) (see note 54), 252-254.348 (viz. f. 28vb,21f. $29 \mathrm{vb}, 18$ and f. $76 \mathrm{va}, 28-\mathrm{b}, 28$ in the basic manuscript). 
However, a more substantial part of the homilies De oratione dominica was translated in 16th century Moscow by Maximus the Greek. ${ }^{56}$ The translation as it is known from one 16th century manuscript ${ }^{57}$ is incomplete and contains, according to the incipit in Ivanov and the references to PG 44 in Bulanin, most of the second homily, ${ }^{58}$ the last part of the fourth and the complete fifth homily. ${ }^{59}$ Translations of 4th century fathers indeed make up an important part of Maximus' work: he translated works of Gregory of Nazianzus, Basil of Caesarea and John Chrysostom-of the bishop of Nyssa only the homilies De oratione dominica. It is most likely, however, that Gregory's writings exerted a considerable influence on the theological views expressed in Maximus' own work, especially with respect to his anthropology. ${ }^{60}$

\section{Ascetic works-Vita s. Macrinae}

Of considerable importance within the whole of Gregory's writings are his ascetic works, the most well known of which is, perhaps, the book De virginitate (CPG 3165). However the De virginitate remained unknown to the Slavs, just as the synthesis of Gregory's views on ascetism expressed in the De instituto christiano (CPG 3162) or in the epistolary treatises De professione christiana (CPG 3163) and De perfectione christiana (CPG 3164). Only Gregory's description of his

${ }^{56}$ See Aleksej Ivanov: Literaturnoe nasledie Maksima Greka: Charakteristika, atribucii, bibliografija (Leningrad: Nauka, 1969), 65 note 61, and Dmitrij Bulanin: Perevody i poslanija Maksima Greka: Neizdannye teksty (Leningrad: Nauka, 1984), 186.

${ }_{57}$ Codex St. Petersburg Russian State Historical Archive 4025, f. 834,3.

58 Or. dom. (GNO VII/2, 20-29 Callahan).

$59 \sim$ Or. dom. (GNO VII/2, 55-74 Callahan). A note in cinnabar in the manuscript explains the hiatus; it reads "Here two quires and two slova (viz. homilies) have been lost, and what he has translated is not complete either" (Ivanov: Literaturnoe nasledie Maksima Greka [see note 56], 65).

${ }^{60}$ Fragments from Maximus' second "Conversation of the Mind with the Soul," for instance, immediately call to mind Gregory's De hominis opificio and De anima et resurrectione - just two excerpts: "But as you [viz. the soul] are created immortal, with intellect, and are eternally imperishable, and being the image of God, you carry with yourself the knowledge of the qualities of your Archetype with which you stand higher than speechless natures [...] and this you have not kept as you ought," or "A mirror covered with a thick layer of dust cannot reflect the luster of the sun's shining, and the soul enslaved by vile passions of the flesh cannot receive the rays of constant, unfading light. Deprived of this, it in no way differs from dumb nature."English translation, with minor alterations, from Jack Haney: From Italy to Muscovy: The Life and Works of Maxim the Greek. Humanistische Bibliothek 1/19 (München: Wilhelm Fink, 1973), 150f. 
sister's ascetic life, the Vita Macrinae (CPG 3166) ${ }^{61}$ was translated in full in the course of the 14th century. As a Vita of the saint, it was included in the Menologium for reading on the day of her feast, July $19 .{ }^{62}$

\section{Orations and sermons}

If one is to speak of the assimilation of any aspect of Gregory's writings, this is first and foremost the case with his homiletic works. Not only do we know a considerable number of translations, Gregory's sermons and orations exerted an influence on original Slavonic writing as well.

Some of Gregory of Nyssa's festal sermons were translated, as is apparent, for instance, from the manuscript collection of the Chilandar Monastery on Athos. The Chilandar library holds some codices containing two of Gregory's festal sermons in Slavonic translation: the first Easter sermon De tridui inter mortem et resurrectionem Domini nostri Iesu Christi spatio (CPG 3175) ${ }^{63}$ is found in three Chilandar homiliaries, which also contain the sermon for the feast of the Ascension, In ascensionem Christi (CPG 3178). ${ }^{64}$

Gregory's Praise of Theodore the Martyr, the Oratio laudatoria sancti ac magni martyris Theodori (CPG 3183) ${ }^{65}$ can also be found in Chilandar manuscripts. ${ }^{66}$ Of Gregory's first sermon on St. Stephen, the Im sanctum Stephanum I (CPG 3186) ${ }^{67}$ three versions are known: ${ }^{68}$

${ }^{61}$ Macr. (GNO VIII/1, 370-414 Callahan).

${ }^{62}$ See Francis Thomson: "The Works by or Ascribed to Gregory of Nyssa in the Hilandar Monastery Slavic Manuscript Collection, together with a few remarks on the Slav Reception of Christianity," in: Monastic Traditions: Selected Proceedings of the Fourth International Hilandar Conference (The Ohio State University, 14-15 August 1998), ed. by Charles Gribble and Predrag Matejic (Bloomington (Indiana]: Slavica, 2003), (342-357) 343-345; for the inclusion of the translation in the Macarian Menologium, see Archemandrite Iosif (Levickij): Podrobnoe oglavlenie Velikich Čet'ich Minej vserossijskogo mitropolita Makarija, chranjaščichsja v Moskovskoj Patriaršej (nyne Sinodal'noj) biblioteke. Vol. 2 (Moscow: Sinodal'naja tipografija, 1892), 319f.

${ }^{63}$ Trid. spat. (GNO IX, 271-306 Gebhardt).

${ }^{64}$ Ascens. (GNO IX, 321-327 Gebhardt). See Thomson: "The Works by or Ascribed to Gregory of Nyssa in the Hilandar Monastery Slavic Manuscript Collection" (see note 62$)$, $346 f$.

${ }^{65}$ Theod. (GNO X/1, 59-71 Cavarnos).

${ }^{66}$ See Thomson: "The Works by or Ascribed to Gregory of Nyssa in the Hilandar Monastery Slavic Manuscript Collection” (see note 62), 347.

${ }^{67}$ Steph. I (GNO X/1, 73-94 Lendle).

${ }^{68}$ See Thomson: "Continuity in the Development of Bulgarian Culture during the Period of Byzantine Hegemony" (see note 5), 143 and "The Works by or Ascribed 
two translations found in Slavonic menologia and homiliaries whose manuscript tradition goes back to the 14th century, and a third version-either a revision of the second translation or a new one-found in 14th century codices and included in the Macarian Menologium sub December $27 .{ }^{69}$ There is an early, 10th century translation of Gregory's De vita Gregorii Thaumaturgi (CPG 3184), ${ }^{70}$ also included in Macarius' Menologium sub November $17 .^{71}$ The Greek original of the panegyric on Gregory Thaumaturgus was also used by Gregory Camblak (c. $1362 / 1371-1419 / 1420)^{72}$ as the main source to write his Praise of Patriarch Euthymius of Tărnovo. ${ }^{73}$

Gregory's In Meletium (CPG 3180) ${ }^{74}$ was also translated into Slavonic. ${ }^{75}$ Moreover, this funeral oration, pronounced over Bishop Meletius of Antioch, is echoed in Gregory Camblak's lament for Metropolitan Cyprian of Kiev (metropolitan 1375-1406). ${ }^{76}$ Camblak

to Gregory of Nyssa in the Hilandar Monastery Slavic Manuscript Collection" (see note 62), 347f., and Hannick: Maximos Holobolos in der kirchenslavischen homiletischen Literatur (see note 1), 168.

${ }_{69}$ See Levickij: Podrobnoe oglavlenie Velikich Čet'ich Minej vserossijskogo mitropolita Makarija (see note 62), vol. 1, 270; cf. Velikie Minei Četii sobrannye vserossijskim mitropolitom Makarijem, dekabr dni 25-31 (Moscow, 1912), 2407-2421.

${ }^{70}$ Thaum. (GNO X/1, 1-57 Heil). See Thomson: "Continuity in the Development of Bulgarian Culture during the Period of Byzantine Hegemony" (see note 5), 143.

${ }^{71}$ See Levickij: Podrobnoe oglavlenie Velikich Čet'ich Minej vserossijskogo mitropolita Makarija (see note 62). Vol. 1, 188; cf. Velikie Minei Četii sobrannye vserossijskim mitropolitom Makarijem, nojabr tetr. II, dni 16-17 (Saint-Petersburg, 1911), 2652-2700; vol. 3, dni 17-22 (Moscow, 1914), 2701-2704.

${ }_{72}$ For Camblak's life see Francis Thomson: "Gregory Tsamblak-the Man and the Myths," Slavica Gandensia 25/2 (1998), 5-149.

${ }_{73}$ Pochvalno slovo za Evtimij ot Grigorij Camblak, ed. by Pen'o Rusev, Ivan Gălăbov and Angel Davidov (Sofija: Bălgarska akademija na naukite, 1971), 112-233; for a contrastive presentation of Camblak's text and fragments of the Greek original, see Julia Alissandratos: Medieval Slavic and Patristic Eulogies. Studia historica et philologica. Sectio Slavica 6 (Florence: Sansoni, 1982), 62-65.

${ }^{74}$ Melet. (GNO IX, 439-457 Spira).

75 Thomson: "Continuity in the Development of Bulgarian Culture during the Period of Byzantine Hegemony" (see note 5), 143; for references to manuscripts see Hannick: Maximos Holobolos in der kirchenslavischen homiletischen Literatur (see note 1), 190 and Thomson: "The Works by or Ascribed to Gregory of Nyssa in the Hilandar Monastery Slavic Manuscript Collection" (see note 62), 348. For the occurrence of the oration in the Macarian Menologium sub February 12, see Levickij: Podrobnoe oglavlenie Velikich Čet'ich Minej vserossijskogo mitropolita Makarija (see note 62), vol. 1,474 .

${ }^{76}$ There is only one known copy, viz. in the Codex Moscow, State Historical Museum Sinod. 384, f. 236r-244r (16th century); Slovoto na Grigorij Camblak za mitropolit Kiprian, ed. by Nevena Dončeva-Panajotova. Biblioteka, filologija, literaturoznanie 1 (Veliko Tărnovo: PIK, 1995), 76-96. For Cyprian's life and work, see Podskalsky: Theologische Literatur des Mittelalters in Bulgarien und Serbien 865-1459 (see note 6), 212-219. 
used both Gregory of Nyssa's and John Chrysostom's eulogies of Meletius as structural models for his work. ${ }^{77}$ Moreover, the oration is shown to have influenced the Life of Stephen of Perm (1340-1396) by Epiphanius the Wise ( $\dagger$ c. 1420), ${ }^{78}$ as well as an anonymous 14 th century eulogy of the Serbian Prince Lazar (1329-1389), who was killed in the battle at Kosovo polje. ${ }^{79}$ Gregory's funeral oration on his brother Basil, the In Basilum fratrem (CPG 3185) ${ }^{80}$ was also translated, presumably during the 14 th century. ${ }^{81}$ The Vita atque encomium sancti patris nostri Ephraem Syri (CPG 3193), ${ }^{82}$ often considered to be spurious, is known only in 17 th century copies. ${ }^{83}$

\section{Canonical letter}

Among the early Slavonic translations were works of canon law, as they were needed to regulate church and state organisation. As in the Greek tradition, where Gregory's Epistula canonica ad Letoium (CPG

77 See Johannes Holthusen: "Neues zur Erklärung des Nadgrobnoe Slovo von Grigorij Camblak auf den moskauer Metropoliten Kiprina," in: Slavistische Studien zum VI internationalen Slavistenkongress in Prag, ed. by Erwin Koschmieder and Maximilian Braun (Munich: Trofenik, 1968), 372-382, also Alissandratos: Medieval Slavic and Patristic Eulogies (see note 73), 89 and by the same author "The structure of Gregory Camblak's eulogy of Cyprian," Palaeobulgarica 6/1 (1982), 45-58.

${ }^{78}$ Žitie sv. Stefana episkopa permskogo, ed. Vasilij Družinin ('s-Gravenhage: Mouton \& Co., 1959) and sub April 26 in Velikie Minei Četii sobrannye vserossijskim mitropolitom Makarijem, aprel' dni 22-30 (Moscow, 1915), 988-1109; see Johannes Holthusen: "Epifanij Premudryj und Gregor von Nyssa (Ein Beitrag zur Erforschung der enkomiastischen Literatur bei den Slaven)," in: Festschrift für Margarete Woltner zum 70. Geburtstag, ed. by Peter Brang, Herbert Braüer, and Horst Jablonowski (Heidelberg: Winter, 1967), 64-82, and Alissandratos: Medieval Slavic and Patristic Eulogies (see note 73), 80-89. For Epiphanius' Life of Stephen, see e.g. Čiževskij: History of Russian Literature (see note 19), 167-171.

79 Edited from a 17th century manuscript: "O knezu Lazaru, iz rukopisa XVII veka koj e u podpisanoga," ed. by A. Vukomanović, Glasnik Društva srbske slovesnosti 11 (1859), 108-118; see Holthusen: "Epifanij Premudryj und Gregor von Nyssa" (see note 78), 66-82, and Alissandratos: Medieval Slavic and Patristic Eulogies (see note 73), 80-89.

${ }^{80}$ Bas. (GNO X/1, 107-134 Lendle).

81 See Hannick: Maximos Holobolos in der kirchenslavischen homiletischen Literatur (see note 1), 171, Thomson: "Continuity in the Development of Bulgarian Culture during the Period of Byzantine Hegemony" (see note 5), 143 and idem: "The Works by or Ascribed to Gregory of Nyssa in the Hilandar Monastery Slavic Manuscript Collection" (see note 62), 348.

${ }^{82}$ Edited in PG 46, col. 820-849.

${ }^{83}$ See Thomson: "The Works by or Ascribed to Gregory of Nyssa in the Hilandar Monastery Slavic Manuscript Collection” (see note 62), 348f. 
$3148)^{84}$ is transmitted exclusively as a part of collections of canon law, the canonical letter is found in the Slavonic Syntagmata xiv titulorum, translated in 9th or 10th century Bulgaria and later adopted in Russia. ${ }^{85}$

\section{Minor fragments}

Besides the translations listed above, a number of dispersed fragments are to be found included as quotations in other texts or scattered in compilations of erotapocritic and gnomological nature. A quotation on God's incomprehensibility from the Contra Eunomium III, for instance, was integrated in an "Opusculum against the Latins," preserved in a 14th century Slavonic translation and attributed to Barlaam of Seminara (c. 1290-1348). ${ }^{86}$ In addition to the above-mentioned fragments of the second and fourth homilies In orationem dominicam, ${ }^{87}$ the Florilegium of Symeon contains passages from Gregory's Oratio catechetica, ${ }^{88}$ De infantibus qui praemature obripiuntur (CPG 3145) ${ }^{89}$ and Contra fatum (CPG 3152). ${ }^{90}$ Some thirty isolated and often heavily distorted sentences from Gregory's writings are included in an anthology called Pčela or "Bee” (Greek Mć̀ı $\sigma \sigma \alpha)$, a collection of quotations

\footnotetext{
${ }^{84}$ Epist. can. (GNO III/5, 1,1-12,22 Mühlenberg).

${ }^{85}$ See Thomson: "Continuity in the Development of Bulgarian Culture during the Period of Byzantine Hegemony" (see note 5), 142; Drevneslavjanskaja kormčaja XIV titulov bez tolkovanij. Vol. 1, ed. with Greek parallel text by Vladimir Beneševič (SaintPetersburg: Typis academiae scientiarum, 1906), 1-837; for the Epistula canonica, see 612-631.

${ }_{86}$ The fragment is found in the Codex Dečan, Kosovo, Visoki Dečani Monastery 88 (14th century), which contains a contemporary Slavonic translation of Gregory

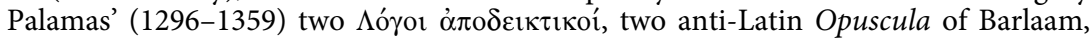
Palamas' treatise against Akyndinos, a treatise on the azymes and two homilies for Good Friday-see Ioannis Kakridis: Codex 88 des Klosters Dečani und seine griechischen Vorlagen: Ein Kapitel der serbisch-byzantinischen Literaturbeziehungen im 14. Jahrhundert. Slavistische Beiträge 233 (München: Otto Sagner, 1988); the excerpt from the Contra Eunomium is on f. $68 \mathrm{r}, 21-68 \mathrm{v}, 11$ : Ioannis Kakridis: "Barlaam von Kalabrien. Gegen die Lateiner: Edition der serbisch-kirchenslavischen Übersetzung nach der Handschrift Decani 88," Chilandarski zbornik 11 (2004), (181-226) 214.

${ }^{87}$ See supra part 2.4 .

88 Or. cat. (GNO III/4, 38,5-23 Mühlenberg). Viz. the sixth (or seventh, depending on wether a gloss to the second preface is counted) preface to the (pseudo-)Anastasian questions; Dinekov: Simeonov sbornik (po Svetoslavovija prepis ot $1073 \mathrm{~g}$.) (see note 54), 228f. (f. 16vb,28-f. 17rb,15).

$89 \sim$ Infant. (GNO III/2, 95,7-17 Horner).

$90 \sim$ Fat. (GNO III/2, 49,11-52,19 McDonough). Appended resp. to the answers of questions sixteen and nineteen, Dinekov: Simeonov sbornik (po Svetoslavovija prepis ot 1073 g.) (see note 54), 389 (f. 97rb,6-28) and 425-428 (f. 115ra,7-f. 116va,10).
} 
from the Bible, the Church Fathers and secular Greek authors on christian and profane ethics. ${ }^{91}$

Apart from Gregory of Nyssa's sermons and orations, a considerable number of which were translated throughout the Slav Middle Ages, none of his writings-be it dogmatic, exegetical or ascetic - reached the Slavs in a full translation before the 14th century, when Vita Macrinae and the treatise De hominis opificio were translated in full. A translation of the homilies De oratione dominica was completed in the 16th century by the Greek Michael-Maximus Triboles, whose remarkable fate it was to become one of Russia's most prominent writers of that time. The scanty sum of this survey is completed by no more than dispersed and often distorted fragments and excerpts. There is no evidence of a profound assimilation of the theological content of Gregory of Nyssa's writings in mediaeval Slavia orthodoxa. The reception of his works was largely fragmentary, on the one hand in that part of his oeuvre reached the Slavs in a piecemeal way and on the other in that the narrow selection from his works failed to do justice to the whole range of his thought. Not as a gifted theologian but only as a hagiographer and a preacher did Gregory gain a foothold on Slav soil. However, it should be noted that some of the greatest minds in the history of Slav Letters-John the Exarch in 10th century Bulgaria, Euthymius of Tărnovo in 14th century Bulgaria and Maximus the Greek in 16th century Russia-seem to have been fairly well acquainted with Gregory's works, a knowledge that was subtly incorporated into their own writings. If some aspects of his thought-e.g. some of his views on anthropology-did indeed seep through, it was due to men of their calibre, combining proficiency in Greek, a clear understanding of the Byzantine Fathers, an active mind and a prolific pen.

91 "Pčela" Drevnerusskij perevod. Vol. 1, ed. by Anna Pičchadze and Irina Makeeva (Moscow: Rukopisnye pamjatniki Drevnej Rusi, 2008); the Pčela excerpts are taken from various works, especially from the De beatitudinibus and the In orationem dominicam, but also from the Vita Moysis, Contra Eunomium, In canticum canticorum, De hominis opificio, In Ecclesiasten, and from the Oratio catechetica. 